\title{
MISCONCEPTION IDENTIFICATION USING THE CERTAINTY OF RESPONSE INDEX METHOD IN GAS KINETIC THEORY MATERIAL IN CLASS XI SENIOR HIGH SCHOOL
}

\author{
Nisa Siti Romadona ${ }^{* 1)}$, Wanda Siti Nur Aulia ${ }^{2)}$, Suci Rizki Lestari ${ }^{3)}$, Nana $^{4)}$ \\ Physics Education, Fakulty Teacher Training and Education of University Siliwangi \\ Email: ${ }^{*}$ nsromadona2@gmail.com \\ sucirizkilestari@gmail.com \\ wandasna@gmail.com \\ nana@unsil.ac.id
}

\begin{abstract}
This research aims to identify class XI MIPAl senior high school students, who experience misconceptions on the kinetic theory of gas. The method used to determine students who experience misconceptions is the Certainty Response Index (IRK) method. This method has four indexes in identifying students' mastery of concepts, namely lucky guess (LG), not knowing concept (NKC/TTK), knowing concept (KC/TK), and misconception (M). The subjects of the study were senior high school students in class XI MIPAI in Tasik Malaya. The research instrument used was a kinetic theory of gas test equipped with an IRK scale assessment instrument. This research is a quantitative descriptive research that can determine weaknesses in understanding students' physics concepts with the IRK method. The results of data analysis using IRK revealed that students who experienced lucky guess $(L G)$ were $9.0 \%$, students who knew the concept (TK) were $35.2 \%$, students who lacked knowledge or did not know the concept (TTK) were 21.9\%, and students experiencing misconceptions (M) of 33.8\%. Based on the sub-topic analysis, the level of misconception the results are also in the high category. Thus it was concluded that through the IRK method it was identified that most students were still experiencing misconceptions, did not know the concepts, and were lucky guessed in understanding the kinetic theory of gas in the class XI MIPAl of senior high school in Tasik Malaya.
\end{abstract}

Keyword: Certainty of Response Index, misconception, gas kinetic theory. 


\title{
IDENTIFIKASI MISKONSEPSI MENGGUNAKAN METODE INDEKS RESPON KEPASTIAN PADA MATERI TEORI KINETIK GAS DI KELAS XI SMA
}

\author{
Nisa Siti Romadona ${ }^{* 1)}$, Wanda Siti Nur Aulia ${ }^{2)}$, Suci Rizki Lestari ${ }^{3)}$, Nana $^{4)}$ \\ Pendidikan Fisika, FKIP, Universitas Siliwangi
}

\begin{abstract}
Abstrak
Penelitian ini bertujuan untuk mengidentifikasi siswa kelas XI MIPA, SMA, yang mengalami miskonsepsi pada materi teori kinetik gas. Metode yang digunakan untuk mengetahui siswa yang mengalami miskonsepsi adalah dengan metode Indeks Respon Kepastian (IRK) atau Certainty of Respon Indeks (CRI). Metode ini memiliki empat indeks dalam mengidentifikasi penguasaan konsep siswa yaitu lucky guess (LG), tidak tahu konsep (TTK), tahu konsep (TK), dan miskonsepsi (M). Subjek penelitian adalah siswa kelas XI MIPA 1 SMA di Tasik Malaya. Instrumen penelitian yang digunakan yaitu soal tes teori kinetik gas yang dilengkapi dengan instrumen penilaian skala IRK. Penelitian ini merupakan penelitian deskriptif kuantitatif yang dapat menentukan kelemahan pemahaman konsep fisika siswa dengan metode IRK. Hasil analisis data menggunakan IRK diketahui siswa yang mengalami lucky guess (LG) sebanyak 9,0\%, siswa yang tahu konsep (TK) sebanyak 35,2\%, siswa yang kurang pengetahuan atau tidak tahu konsep (TTK) sebanyak 21,9\%, dan siswa mengalami miskonsepsi (M) sebanyak 33,8\%. Berdasarkan analisis sub pokok bahasan, tingkat miskonsepsi hasilnya juga dalam kategori tinggi. Dengan demikian disimpulkan bahwa melalui metode IRK diidentifikasi bahwa sebagian besar siswa masih mengalami miskonsepsi, tidak tahu konsep, dan lucky guess dalam memahami teori kinetik gas di kelas XI MIPA 1 SMA di Tasik Malaya.
\end{abstract}

Kata kunci : indeks kepastian respon, miskonsepsi, teori kinetik gas.

\section{Pendahuluan}

Pendidikan merupakan suatu hal yang terpenting, sehingga semua orang berhak mendapatkan dan terus berjuang untuk selalu tumbuh dan berkembang dengan pendidikan. Pendidikan termasuk proses kehidupan dalam mengembangkan diri bagi tiap individu agar menjadi orang yang terdidik. Pendidikan terjadi di lingkungan keluarga, sekolah dan masyarakat.

Berbagai macam ilmu pengetahuan diajarkan di sekolah, termasuk ilmu sains. Ilmu sains memiliki banyak cabang seperti biologi, kimia, ilmu bumi, dan fisika termasuk salah satunya. Menurut Saregar (2016) fisika merupakan salah satu mata pelajaran dalam rumpun sains yang sangat erat kaitannya dengan kehidupan sehari-hari. Tujuan pembelajaran fisika pada hakikatnya adalah untuk mengantarkan konsep-konsep dan keterkaitannya untuk dapat memecahkan masalah dalam kehidupan sehari-hari (Yuwarti et al., 2017; Sunarti et al., 2018).

Seorang siswa dikatakan paham dalam mengikuti pembelajaran apabila mereka dapat mengkonstruksi makna dari pesan-pesan pembelajaran, baik yang bersifat lisan, tulisan ataupun grafis, yang disampaikan melalui pengajaran, buku, atau layar komputer (Irwandi, 2015). Namun pada faktanya pelajar di tingkat SMA mengalami kesulitan saat belajar fisika. Sifat mata pelajaran fisika salah satunya adalah bersyarat, artinya setiap konsep baru adakalanya menuntut prasyarat pemahaman atas konsep sebelumnya (Rusliowati, 2006). Oleh karena itu, bila terjadi kesulitan belajar pada salah satu pokok bahasan, akan terbawa ke pokok bahasan berikutnya, atau bila terjadi miskonsepsi akan terbawa sampai jenjang pendidikan berikutnya.

Fisika juga merupakan pelajaran yang mempelajari banyak konsep mulai dari konsep yang sederhana sampai suatu konsep yang lebih kompleks. Menurut Nana (2018), miskonsepsi telah terjadi apabila pemahaman siswa terhadap suatu konsep berbeda dengan apa yang dimaksud oleh masyarakat ilmiah atau siswa memberikan pemahaman yang berbeda terhadap suatu konsep dengan apa yang dimaksud oleh kurikulum atau bukubuku acuan yang menjadi pegangan.

Menurut Zahra \& Suprapto (2019), untuk 
memperoleh pemahaman tentang fakta, konsep, prinsip, hukum dan teori melalui proses berpikir ilmiah, proses pembelajaran fisika tidak hanya menyajikan ide-ide baru pada siswa, melainkan mengubah ide-ide lama yang dimiliki siswa, karena pada saat siswa memasuki tahap belajar yang baru, siswa tidak datang dengan pikiran kosong, melainkan sudah memiliki pengetahuan dari pengalamannya sehari-hari dan informasi yang didapatkan dari lingkungan.

Menurut Van den Berg (dalam Tayubi, 2005), hasil penelitian menunjukkan bahwa miskonsepsi terjadi secara universal di seluruh dunia bagaimanapun lingkungan, sosial budaya, bahasa maupun etniknya. Konsepsi dan miskonsepsi siswa diduga terbentuk pada masa anak dalam interaksi otak dengan alam. Sejak kecil anak berpengalaman dengan alam sekitarnya, anak yang menggerakkan mainan telah memperoleh pengalaman yang berhubungan dengan konsep gaya, momentum, kecepatan dan percepatan. Walaupun istilah itu memang belum digunakan, maka di dalam otaknya sudah terbentuk konsepsi atau miskonsepsi yang berhubungan dengan konsep-konsep tersebut.

Miskonsepsi siswa tidak terlepas oleh adanya penyebab atau sumber dari ketidaksesuaian konsep. Terjadinya miskonsepsi dapat disebabkan oleh beberapa sumber, yaitu dari siswa, guru, buku teks yang digunakan, konteks, dan cara mengajar guru (Suparno dalam Syahrul \& Setyarsih, 2015). Miskonsepsi yang terjadi pada siswa dipengaruhi berbagai macam faktor dan terjadi tidak disadari, oleh sebab itu diperlukan adanya identifikasi untuk mengetahui apakah siswa mengalami miskonsepsi atau tidak (Alawiyah, 2017). Maka perlu dilakukan identifikasi untuk mengetahui miskonsepsi yang dialami siswa, sehingga siswa dan guru dapat mengetahui fakta yang sebenarnya terjadi dan kemudian dapat mempersiapkan diri untuk menindaklanjuti permasalahan tersebut. Berbagai macam cara dapat digunakan untuk mengidentifikasi miskonsepsi pada siswa diantaranya adalah menggunakan peta konsep, tes pilihan ganda dengan alasan terbuka, tes esai tertulis, wawancara, diskusi dalam kelas hingga praktikum tanya jawab (Suparno dalam Harizah, 2017).

Cara lain yang digunakan untuk mengidentifikasi miskonsepsi pada siswa adalah dengan Indeks Respon Kepastian (IRK). Hasan et al. (1999), telah memberikan suatu metode yang bisa digunakan untuk mengidentifikasi miskonsepsi yaitu dengan menggunakan metode Indeks Respon Kepastian (IRK). Metode ini merupakan nama lain dari metode Certainly Response Indeks (CRI). Metode IRK selain mampu untuk mengidentifikasi miskonsepsi sekaligus juga mampu membedakannya dengan siswa yang tidak tahu konsep.

Penelitian ini dilakukan untuk mengetahui siswa yang mengalami lucky guess (LG), siswa yang tahu konsep (TK), siswa yang tidak tahu konsep (TTK) dan siswa yang mengalami miskonsepsi (M) terkait pemahaman konsep siswa pada materi teori kinetik gas di salah satu SMA di Tasikmalaya dengan menggunakan metode Indeks Respon Kepastian (IRK).

\section{Bahan dan Metode}

Penelitian ini menggunakan metode deskriptif kuantitatif. Penelitian dilakukan di salah satu SMA yang ada di Tasikmalaya yang subjek respondennya terhadap 21 orang siswa kelas XI MIPA ${ }_{1}$. Teknik pengumpulan data dilakukan dengan cara siswa kelas XI MIPA mengisi google form yang berisi soal pilihan ganda sebanyak 10 soal terkait materi teori kinetik gas. Dengan konsep yang telah diujikan, dilakukan analisis grafik perubahan fasa zat, memahami gas ideal, dan pada sub bab teori kinetik gas yaitu menghitung dan menganalisis energi kinetik dan menghitung kecepatan gas ideal. Setiap soal terdapat pertanyaan keyakinan diri mereka dalam menjawab soal yang diberikan. Skala keyakinan menjawab soal disesuaikan berdasarkan skala IRK pada Tabel 1.

Angka 0 pada skala IRK menyatakan bahwa siswa tidak mengetahui sama sekali mengenai metode-metode atau hukum-hukum yang digunakan dalam menjawab persoalan, sedangkan angka 5 menyatakan kepercayaan diri siswa yang besar atas pengetahuan yang dia miliki tanpa ada unsur menebak. Apabila derajat kepastiannya rendah (IRK berada pada skor 0-2), berarti hal ini mencerminkan bahwa proses menebak jawaban sangat besar dalam menentukan jawaban yang sudah dipilih. Tanpa memikirkan apakah jawaban yang dipilih sudah benar atau tidak, sedangkan IRK 
yang skalanya tinggi (IRK 3-5), membuktikan bahwa siswa mempunyai tingkat keyakinan diri yang besar dalam menjawab suatu persoalan.

Tabel 1. Skala IRK dan kriterianya

\begin{tabular}{cl}
\hline IRK & \multicolumn{1}{c}{ Kriteria } \\
\hline 0 & $\begin{array}{l}\text { Untuk jawaban yang benar-benar tidak } \\
\text { tahu (totally guess answer) }\end{array}$ \\
1 & $\begin{array}{l}\text { Untuk jawaban yang agak tahu (almost } \\
\text { guess) }\end{array}$ \\
2 & $\begin{array}{l}\text { Untuk jawaban yang tidak yakin (not } \\
\text { sure) }\end{array}$ \\
3 & Untuk jawaban yang yakin (sure) \\
4 & $\begin{array}{l}\text { Untuk jawaban yang agak pasti (almost } \\
\text { certain) }\end{array}$ \\
5 & $\begin{array}{l}\text { Untuk jawaban yang sangat pasti } \\
\text { (certain) }\end{array}$ \\
\hline
\end{tabular}

Sumber: (Tayubi, 2005).

Menurut Tayubi (2005), IRK adalah ukuran suatu keyakinan siswa dalam menjawab setiap pernyataan yang diberikan. Secara khusus, dalam sebuah pernyataan tes yang berbentuk pilihan ganda, siswa diintruksikan untuk:

a. Memberikan suatu jawaban yang dianggap benar dari pilihan jawaban yang disediakan.

b. Memberikan skala IRK dari 0-5, untuk semua jawaban yang sudah terpilih. IRK 0 diberikan jika jawaban yang dipilih hasil menebak, sedangkan IRK 5 diberikan jika jawaban yang dipilih atas dasar kemampuan yang sangat siswa yakini.

Selanjutnya hasil dari menjawab soal dan pemberian skala IRK pada setiap soal akan dikategorikan menjadi empat macam, sesuai Tabel 2. Untuk kriteria lucky guess (LG) bisa juga dikategorikan sebagai siswa yang kurang percaya diri atau asal menebak jawaban. Untuk mempermudah responden dalam menjawab soal IRK yang diberikan, maka apabila siswa dalam mengerjakan soal dengan benar tetapi dengan skala kurang dari 0-2 maka siswa tersebut mengalami lucky guess (LG), apabila mengerjakan soal dengan benar dengan skala lebih dari 0-2 maka siswa tersebut dinyatakan tahu konsep (TK). Sedangkan apabila siswa mengerjakan soal dengan salah tetapi dengan skala kurang dari 2-5 maka siswa tersebut tidak tahu konsep (TTK), apabila siswa mengerjakan soal dengan salah tetapi dengan skala lebih dari 2-5 maka siswa mengalami miskonsepsi (M).

Tabel 2. Ketentuan membedakan tahu konsep, miskonsepsi dan tidak tahu konsep

\begin{tabular}{lll}
\hline $\begin{array}{c}\text { Kriteria } \\
\text { Jawaban }\end{array}$ & \multicolumn{1}{c}{$\begin{array}{c}\text { IRK Rendah } \\
(<\mathbf{2 , 5})\end{array}$} & $\begin{array}{c}\text { IRK Tinggi } \\
(\mathbf{2 , 5})\end{array}$ \\
\hline Jawaban & Jawaban benar & Jawaban benar \\
benar & tapi IRK & dan IRK \\
& rendah berarti & Tinggi berarti \\
& tidak tahu & menguasai \\
& (lucky guess & konsep dengan \\
& Laik (TK) & Jawan salah \\
& Jawaban salah & Jawaban san \\
Jawaban & dan IRK & dan IRK tinggi \\
salah & rendah berarti & berarti \\
& tidak tahu & miskonsepsi \\
& konsep (TTK) & (M) \\
\hline
\end{tabular}

Tahap pengolahan data dilakukan sebagai bagian akhir dan akan menjadi kesimpulan dari data yang diperoleh. Pengolahan data dilakukan dengan mengelompokkan data ke dalam empat kelompok berdasarkan Tabel 2 . Selanjutnya dilakukan perhitungan dengan menggunkan rumus (1) yang dikemukakan oleh (Sudijono dalam Alawiyah, 2017), yaitu:

$$
P=\frac{f}{N} \times 100 \%
$$

dengan:

$$
\begin{aligned}
& \mathrm{P}=\text { presentase jawaban siswa } \\
& f=\text { frekuensi siswa yang menjawab soal } \\
& \mathrm{N}=\text { banyaknya siswa }
\end{aligned}
$$

\section{Hasil dan Pembahasan}

Berdasarkan hasil penelitian melalui responden dari 21 siswa kelas XI MIPA 1 menggunakan soal pilihan ganda pada materi teori kinetik gas, diperoleh hasil tes responden menurut Tabel 3. Melalui Tabel 3 dapat diketahui bahwa persentase kriteria lucky guess hanya mencapai $9,0 \%$, artinya berada pada kategori sangat rendah. Persentase tahu konsep dan miskonsepsi, berdasarkan hasil penelitian menunjukkan hasil yang tidak berbeda jauh yaitu dengan persentase 35,2\% untuk kriteria tahu konsep dan persentase 33,8\% untuk kriteria miskonsepsi. Hal tersebut berarti kedua kriteria ini ada pada kategori sangat tinggi. Selanjutnya kriteria tidak tahu 
konsep memiliki persentase yang cukup tinggi yaitu sebesar 21,9\%. Berdasarkan hasil perolehan IRK diketahui bahwa siswa masih belum menguasai dengan baik materi teori kinetik gas.

Tabel 3. Hasil tes teori kinetik gas terhadap Responden

\begin{tabular}{clc}
\hline No & \multicolumn{1}{c}{ Kriteria IRK } & $\begin{array}{c}\text { Persentase } \\
(\mathbf{\%})\end{array}$ \\
\hline 1 & Lucky Guess (LG) & 9,0 \\
2 & Tahu Konsep (TK) & 35,2 \\
3 & Tidak Tahu Konsep (TTK) & 21,9 \\
4 & Miskonsepsi (M) & 33,8 \\
\hline
\end{tabular}

Konsep yang diuji dalam penelitian ini diantaranya menganalisis grafik perubahan fasa zat, memahami gas ideal, dan pada subbab teori kinetik gas yaitu menghitung dan menganalisis energi kinetik serta menghitung kecepatan gas ideal. Setiap konsep diwakili dari masing-masing soal dengan perbandingan 1:4:5. Pembahasan dari masing-masing butir soal mengikuti ketentuan jawaban berdasarkan
IRK pada Tabel 2 dimana jawaban siswa dibagi menjadi 4 bagian yaitu lucky guess (LG) jika siswa menjawab benar dan IRK rendah $(<2,5)$, tahu konsep (TK) jika siswa menjawab benar dan IRK tinggi $(>2,5)$, tidak tahu konsep (TTK) jika siswa menjawab salah dan IRK rendah $(<2,5)$, dan miskonsepsi (M) jika siswa menjawab salah dan IRK tinggi $(>2,5)$.

Menurut Hasan et al. (1999) seorang responden yang mengalami miskonsepsi dan tidak tahu konsep dapat dibedakan secara sederhana dengan membandingkan benar tidaknya jawaban suatu soal dengan tinggi rendahnya indeks kepastian jawaban yang diberikan untuk soal tersebut. Pada penelitian ini membandingkan siswa yang tahu konsep dengan siswa yang mengalami miskonsepsi. Dengan metode membandingkan jawaban benar suatu soal dengan kriteria indeks kepastian. Adapun persentase pada setiap sub pokok bahasan teori kinetik gas ditunjukkan pada Gambar 1.

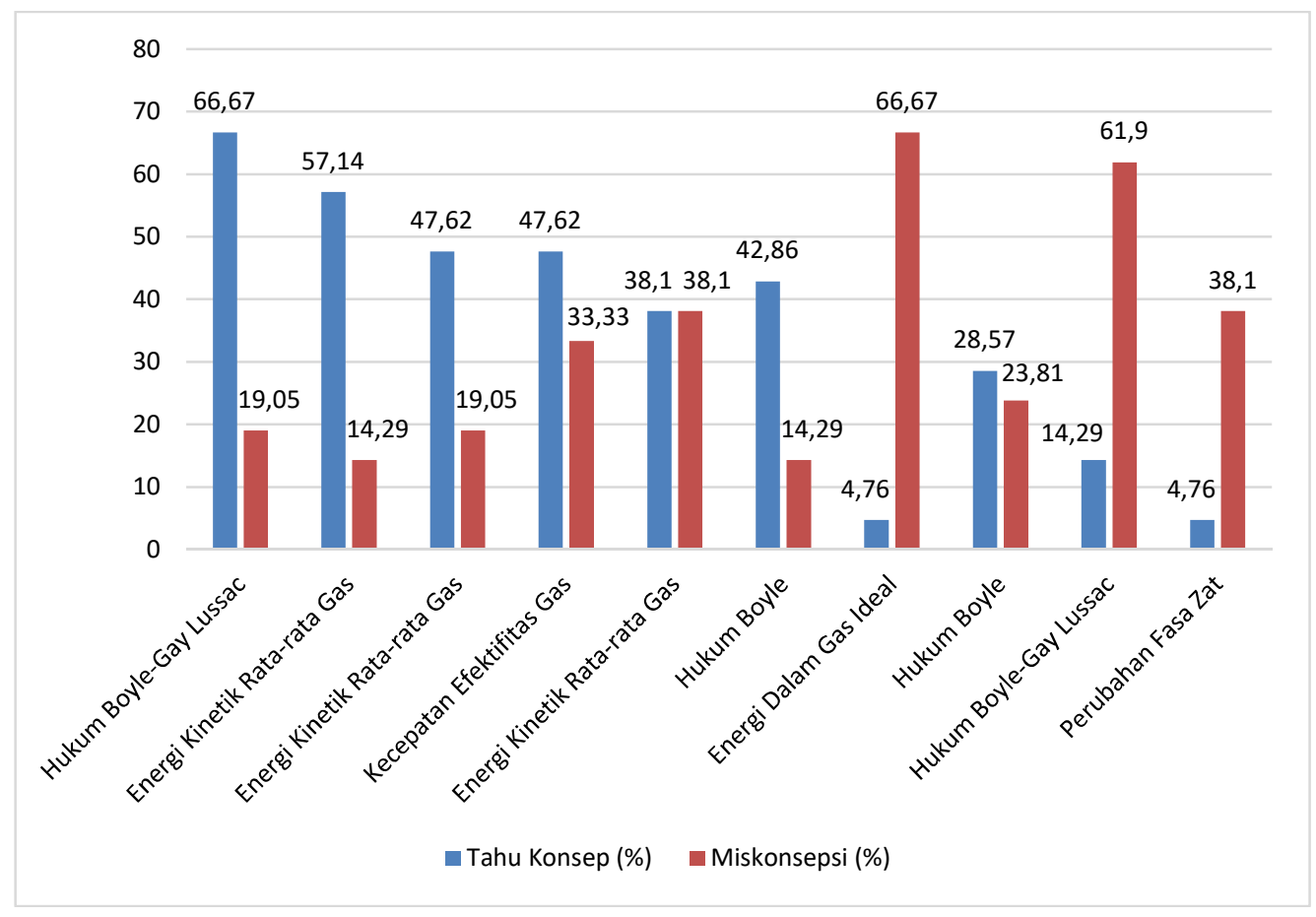

Gambar 1. Persentase rata-rata penguasaan konsep dan miskonsepsi siswa. 
Berdasarkan Gambar 1, hasil analisisis penguasaan konsep dan miskonsepsi pada setiap sub pokok bahasan teori kinetik gas, pada setiap item soal masih banyak siswa yang mengalami miskonsepsi terutama pada nomor 7 yaitu pokok bahasan Energi pada Gas Ideal dengan persentase sebesar 66,67\%. Kemudian diurutan kedua, pokok bahasan yang memiliki kriteria miskonsepsi yang tinggi adalah pada nomor 9 yaitu pokok bahasan Hukum BoyleGay Lusac pada bahasan penerapan hukum Boyle-Gay Lusac pada ban kempes dengan persentase $61,9 \%$. Pada urutan ketiga yang memiliki miskonsepsi tertinggi adalah pada nomor 10 yaitu pokok bahasan perubahan fasa zat pada bahasan menganalisis grafik perubahan fasa zat, miskonsepsi yang terjadi sebesar 38,1\%. Kebanyakan siswa yang mengalami miskonsepsi hal ini dilihat dari kriteria keyakinan atas jawaban yang diberikan siswa.

Mikonsepsi yang terjadi ini, disebabkan karena kekeliruan siswa karena terkecoh akan pilihan-pilihan yang ada pada soal. Seperti pada nomor 9, terdapat pilihan yang sengaja untuk mengecoh siswa yaitu volume gas berkurang, volume gas meningkat, dan tekanan gas berkurang. Pada ban kempes terjadi karena penyusustan udara di dalam ban (volume berkurang) yang disebabkan karena suhu udara di dalam ban meningkat sehingga tekanan udara di dalam pun akan meningkat pula. Pada nomor 10, terdapat pilihan yang mengecoh yaitu gas; menyumblim dan gas; mengkristal. Berdasarkan hasil tersebut diketahui, bahwa siswa masih belum mampu membedakan antara keadaan menyumblim dan mengkristal serta kurangnya kemampuan membaca permasalahan pada grafik.

Hasil penelitian menunjukkan bahwa siswa kesulitan dalam menjawab mengenai teori kinetik gas yaitu energi pada gas ideal, penerapan hukum Boyle-Gay Lusac, dan grafik perubahan fasa zat. Dari ketiga soal yang diberikan, siswa memiliki penguasan materi yang cukup baik, hanya saja karena materi diajarkan pada semester 1 , maka ada kemungkinan siswa sudah mulai lupa.

Kemampuan siswa terhadap penguasaan konsep berbeda-beda tingkatan, dikarenakan tingkat fokus siswa dalam menyimak materi yang disampaikan oleh guru. Selain itu, yang muncul dari diri siswa adalah kurang berlatihnya menjawab, siswa kurang cakap dalam memahami soal-soal yang diberikan. Selain itu, siswa sudah memiliki pemikiran yang didapatkan dari pengalamannya seharihari di lingkungan siswa, termasuk di sekolah. Pemikiran diawal yang salah dan cenderung sudah melekat pada diri siswa, akan sulit untuk dibenarkan, sehingga akan timbul miskonsepsi pada siswa. Faktor lainnya adalah kurang efektifnya media dan metode pembelajaran juga memungkinkan timbulnya miskonsepsi tersebut, sehingga siswa kurang leluasa memahami konsep-konsep dasar fisika dan akhirnya miskonsepsi pada diri siswa masih tetap bertahan.

Berdasarkan hasil analisis data menggunakan metode Indeks Respon Kepastian (IRK) dapat diidentifikasi miskonsepsi siswa yang hampir sebanding dengan siswa yang tahu konsep teori kinetik gas. Perbandingan tingkat pemahaman konsep dan miskonsepsi siswa kelas XI MIPA 1 SMA tidak berbeda jauh. Analisis soal per-sub pokok bahasan juga diperoleh tingkat miskonsepsi yang tertinggi. Oleh karena itu, melalui metode IRK mampu menunjukkan besar tingkat miskonsepsi yang dialami siswa dalam mempelajari teori kinetik gas di kelas XI MIPA 1 SMA. Selain itu, dengan IRK juga dapat mengidentifikasi indeks Lucky Guess, Tahu Konsep, dan Tidak Tahu Konsep yang dialami siswa terkait pemahaman konsep teori kinetik gas.

\section{Kesimpulan}

Berdasarkan hasil pembahasan didapatkan bahwa dengan menggunakan metode Indeks Respon Kepastian (IRK) dapat mengidentifikasi miskonsepsi yang dialami siswa yaitu 9,0\% mengalami lucky guess (LG), $35,2 \%$ siswa tahu konsep (TK), 21,9\% siswa yang tidak tahu konsep (TTK) dan 33,8\% siswa miskonsepsi (M). Berdasarkan analisis sub pokok bahasan, tingkat miskonsepsi juga berkategori tinggi. Dengan metode IRK diidentifikasi bahwa sebagian besar siswa masih mengalami miskonsepsi, tidak tahu konsep dan lucky guess dalam memahami teori kinetik gas di kelas XI MIPA 1 SMA di Tasik Malaya.

Berdasarkan hasil pembahasan, dapat direkomendasikan agar guru dapat menerapkan strategi pembelajaran yang sesuai guna mengatasi miskonsepsi termasuk yang tidak 
tahu konsep dan lucky guess pada siswa. Strategi yang digunakan diharapkan dapat memberikan penekanan pada pemahaman konsep daripada persamaan matematis saja. Praktikum secara virtual juga dapat membantu meningkatkan pemahaman siswa, jika dirasa praktikum secara langsung memerlukan waktu dan biaya yang cukup banyak.

\section{Daftar Pustaka}

Alawiyah, N.S. (2017). Identifikasi miskonsepsi siswa menggunakan metode indeks respon kepastian (IRK) pada Materi Impuls dan Momentum Linear di SMAN 2 Banda Aceh. ETD Unsyiah.

Syahrul, D.A., \& Setyarsih, W. (2015). Identifikasi miskonsepsi dan penyebab miskonsepsi siswa dengan Three-tier Diagnostic Test pada materi Dinamika Rotasi. Inovasi Pendidikan Fisika, 4(3), 67-70.

Harizah, Z. (2017). Penggunaan Three-Tier Diagnostic Test untuk identifikasi miskonsepsi siswa pada materi Teori Kinetik Gas. Inovasi Pendidikan Fisika, 5(3).

Hasan, S., Bagayoko, D., \& Kelley, E.L. (1999). Misconceptions and the certainty of response index (CRI). Physics Education, 34(5), 294.

Irwandani, I. (2015). Pengaruh model pembelajaran generatif terhadap pemahaman konsep fisika pokok bahasan Bunyi peserta didik MTs Al-Hikmah Bandar Lampung. Jurnal Ilmiah
Pendidikan Fisika Al-Biruni,4(2), 165177.

Nana, N. (2018). Penggunaan pendekatan konflik untuk remediasi miskonsepsi pembelajaran suhu dan kalor. In Prosiding SNPS (Seminar Nasional Pendidikan Sains, (pp. 8-14).

Rusilowati, A. (2006). Profil kesulitan belajar fisika pokok bahasan kelistrikan siswa SMA di kota Semarang. Jurnal Pendidikan Fisika Indonesia, 4(2).

Saregar, A. (2016). Pembelajaran pengantar fisika kuantum dengan memanfaatkan media phet simulation dan LKM melalui pendekatan saintifik: Dampak pada minat dan penguasaan konsep mahasiswa. Jurnal Ilmiah Pendidikan Fisika AlBiruni, 5(1), 53-60.

Sunarti, S., Pasaribu, M., \& Hatibe, A. (2018). Pengaruh model pembelajaran ASSURE terhadap hasil belajar siswa pada materi suhu dan kalor. Musamus Journal of Science Education, 1(1), 009-020.

Tayubi, Y. R. (2005). Identifikasi miskonsepsi pada konsep-konsep fisika menggunakan Certainty of Response Index (CRI). Mimbar Pendidikan, 3(24), 4-9.

Yuwarti, Y., Pasaribu, M., \& Hatibe, A. (2017). Analisis pemahaman konsep vektor pada siswa SMA Negeri 5 Palu. JPFT (Jurnal Pendidikan Fisika Tadulako Online), 5(3), 12-15.

Zahra, Y., \& Suprapto, N. (2019). Analisis kualitas instrument four-tier diagnostic test untuk mengidentifikasi profil konsepsi siswa pada materi teori kinetic gas. Inovasi Pendidikan Fisika, 8(3). 